\title{
CLÁUSULA DE NÃO-CONCORRÊNCIA EM CONTRATO INDIVIDUAL DE TRABALHO
}

Estêvão Mallet"

\begin{abstract}
Resumo:
O artigo examina a cláusula de não-concorrência no contrato de trabalho no Direito brasileiro. Afirma sua licitude e considera os limites que devem ser observados no seu estabelecimento, a necessidade de compensação econômica pela restrição imposta, a forma do ajuste, bem como sua interpretação, além de aspectos ligados ao descumprimento da obrigação assumida.
\end{abstract}

Palavras-chave: Contrato de trabalho. Concorrência. Cláusula de não-concorrência. Liberdade de trabalho.

\begin{abstract}
:
The article is about the non-competition clause in labor contracts in Brazilian Labor Law. It states the legitimacy of the agreement and examines its limits, including the need of economic compensation due to imposed restrictions. its form. interpretation, as well as aspects related to the violation of the violation of this obligation.
\end{abstract}

Keywords: Labor Contract. Competition. Non-competition clauses. Freedom to work.

\section{Introdução}

Nas sociedades menos adiantadas, pouco desenvolvidas, centradas na propriedade de terras e organizadas com base em atividades agrícolas ou pecuárias, a informação e o conhecimento técnico têm menor importância. As formas de produção, conhecidas por todos, ou por quase todos, mostram-se mais simples e rudimentares. Transmitem-se. de uma geração para outra, de modo empírico, sem reservas ou cuidado, sofrendo modificações lentas, com pouca diversidade ao longo de séculos ou até de milênios. Mesmo a maneira como vivem as pessoas quase nada se altera, o que levou Raymond Aron a escrever: "entre a Antigüidade e o mundo de ontem havia uma diferença minima em termos de possibilidades técnicas. Para viajar de Roma a Paris - prossegue o mesmo autor . César levava mais ou menos o mesmo tempo que Napoleão" "Novas descobertas ocorrem de forma bastante espaçada, até porque a pesquisa tecnológica

Professor Associado de Direito do Trabalho da Faculdade de Direito da Universidade de São Paulo e advogado.

1 ARON. Raymond. Dezoito lições sobre a sociedade industrial. São Paulo: Martins Fontes, 1981. p. 61. 
permanece essencialmente bloqueada, atraindo minguada atenção." Em síntese. o valor estratégico das técnicas de produção, do conhecimento e das informações em geral é muito menor.

Com a consolidação da indústria, todavia, o quadro se modifica radicalmente. $\mathrm{O}$ conhecimento, muito mais do que a propriedade de terras, passa a tur grande importância. A informação torna-se exigência técnica da indústria moderna. ${ }^{3} \mathrm{~F}$ as novas descobertas logo se transformam em ativos de enorme relevância econômica. A aplicação cada vez mais rápida da ciência na tecnologia faz com que se encurte a viagem do laboratório ao mercado. ${ }^{4}$ Não são raros, aliás, os casos de idéias que, com muito pouco ou quase nenhum capital, permitiram a construção de fortunas. Nas palavras de Habermas, "u uplicuşão da ciência na forma de técnicas e a retro-aplicução dos progressos técnicos na investigução transformaram-se na substância do mundo do trabalho" "

Nesse novo quadro, regular e disciplinar o uso do conhecimento adquire relevância. Se antes não se cuidava de bem de grande valor, já que dominado por muitos, sua proteção, quando se transforma em ativo cobiçado, passa a têr importância, até mesmo para favorecer e estimular novas pesquisas e a continuidade do desenvolvimento. ${ }^{6}$ No campo trabalhista, o problema surge, ım uma de suas facetas, com a possibilidade de uso de conhecimento adquirido pelo empregado, durante a execução do contrato de trabalho e por conta disso, após a extinção do vínculo empregatício, em beneficio não mais do antigo empregador mas. sim. em favor do novo. A pretensão de limitar-se o uso desse conhecimento envolve o exame da licitude da chamada cláusula de não-concorrência no contrato individual de trabalho.

\section{A legislação brasileira}

A legislação trabalhista brasileira mostra-se quase que completamente omissa, no particular. Cogitou apenas da justa causa consistente na concorrência praticada pelo empregado durante a vigència do contrato de trabalho e na violação de segredo da empresa. nos termos do art. 482, alineas "c" e "g". da CL.T. Subjacente às duas normas. especialmente à última, também se acha, não é dificil perceber, a preocupação com a indevida utilização, pelo empregado, de informações obtidas em decorrência do contrato

\footnotetext{
Cf. DE MASI. Domenico. I/ fufuro dei lavoro. Rizzoli: Milano, 1999. p. 65.

Cf. GALBRAITH, John Kenneth. Le nowvel état industriel. Paris: Gallimard, 1979. p. 101.

ALONSO OLEA, Manuel. Introdução ao direito do trabalho. Curitíba: Gênesis, 1997. p. 317.

Progresso técnico e mundo social da vida. In: Técnica e ciência como ideologia. Portugal: Edições 70. p. 99.

Cf., sob a ótica da proteção da invenção industrial, SALOMÃO FILHO, Calixto. Condutas tendentes à dominação dos mercados - Análise juridica. São Paulo. s. e. p. (lese), 2001. p. 149
} 
de trabalho. ${ }^{7}$ Mas a previsão legal longe está de esgotar o problema. Fla supõe, na verdade, a vigência do contrato de trabalho. tanto que cria hipótese de rescisão motivada, em decorrência de justa causa praticada pelo empregado. Mas o uso indevido de informação e a concorrência ilegítima ocorrem, no mais das vezes, após a extinção do contrato, quando a cláusula limitativa da liberdade de trabalho do empregado adquire. então, maior importância e relevância prática.

\section{Licitude da cláusula de não-concorrência}

A omissão da legislação trabalhista na disciplina da cláusula de nãoconcorrência, voltada a impedir ou limitar o exercício de certas atividades pelo empregado, após a extinção de seu contrato de trabalho, faz com que se ponha até mesmo em dúvida a licitude da pactuação. Há quem a considere inconstitucional, por contrastar com a liberdade de trabalho, assegurada pelo art. $5^{\circ}$, inciso XIII. da Constituição. Certa feita foi-se ainda além, afirmando-se o atrito da restrição também com a regra do art. 170, inciso VIII, da ('onstituição, que inclui, entre os princípios da ordem econômica nacional, a busca do pleno emprego. ${ }^{8}$ Tal conclusão, embora tenha sido também acolhida pelo Supremo Tribunal Federal, ao tempo da C'onstituição de 1967," não se afigura correta.

Em primeiro lugar, nenhum direito reveste-se de caráter absoluto. " $A l$ concetto di diritto adverte Ferrara - non è incompatibile quello di limite, anzi vi è inerente" ${ }^{10}$ Não se passa de modo diverso com o direito de exercício de trabalho, tutelado pelo art. $5^{\circ}$ inciso XIII, da Constituição, que tampouco é absoluto, consoante reiteradamente enfatizado pela jurisprudência. " $\mathrm{E}$ tanto é assim que as alíneas "c" e "g",

Cf. DELGADO, Mauricio Godinho. Curso de direito do rrabalho. São Paulo: LTr, 2002. p. 1.173.

× O acórdão em quc assim se decidiu contém a seguinte ementa: "Cláusula de não-concorrência. Cumprimento após a rescisão contratual. llegalidade. A ordem econômica é fundada, também, na valorização do trabalho. tendo por fim assegurar a todos existência digna, observando dentre outros princípios a busca do pleno emprego. Pelo menos, assim está escrito no art. 170, inciso VIII, da Constituiçāo. $U$ art. $6^{\circ}$ do diploma deu ao trabalho grandeza fundamental. A força de trabalho é o bem retribuido com o salário e assim meio indispensável ao sustento próprio e familiar. tanto que a ordem social tem nele o primado para alcançar o bem-estar e a justiça sociais. Finalmente, o contrato de trabalho contempla direitos e obrigações que se encerram com sua extinção. Por tudo. cláusula de não-concorrência que se projeta para após a rescisão contratual é nula de pleno direito, a teor do que estabelece o artigo $9^{\circ}$ da Consolidação das Leis do Trabalho" (TRT - 2 ${ }^{\mathrm{a}}$ Reg., $8^{\mathrm{a}}$ T., RO n. 20010487101 . Rel. Juiz José Carlos da Silva Arouca, Ac. n. 20020079847 in DJ de 05.03.02).

9 Afirmou-se, na oportunidade: "Liberdade de trabalho. Cláusula pela qual o empregado, que fez cursos técnicos às expensas do empregador, obrigou-se a não servir a qualquer impresa concorrente nos 5 anos seguintes, ao fím do contrato. Não viola 0 art. $150, \S 23$ da Constituição o acórdão que declarou inválida tal avenca".(STF - Pleno, RE n. 67.653/GB, Rel. Aliomar Baleeiro, julg. 20,05.70 in DJU de 03.11.70).

10 Tratlato di diritto civile italiano. Roma: Athenaeum, 1921. p. 393.

11 "O art. $5^{\circ}$. XIII, da CF/88. embora assegure o livre exercicio profissional, não contempla uma liberdade absoluta, admitindo a Magna Carta que o legislador ordinário faça restriçōes de acordo com a natureza da 
do art. 482, da CLT, embora limitem, de alguma forma. a possibilidade de trabalho pelo empregado, nunca foram consideradas inconstitucionais. Ademais, mesmo em face de texto mais amplo, como o do art. $72, \S 24$, da Constituição de 1891 , em que se garantia "o livre exercicio de qualquer profissão moral, intellectual e industrial", a doutrina não hesitou em identificar a existência de limites implícitos, relacionados com a proteção de valores socialmente relevantes. ${ }^{2}$ Não é sem importância registrar que também nos Estados Unidos da América, em que a legislação federal pró́be genericamente, e de forma aparentemente ampla, qualquer acordo ou ajuste contrário à liberdade de comércio, ${ }^{13}$ as cláusulas de não-concorrência em contrato de trabalho são admitidas e consideradas legítimas. ${ }^{14}$ Do mesmo modo, a Organização Internacional do Trabalho, já em 1928 adotou resolução favorável à validade, em tese e respeitados certos limites, de cláusulas de não-concorrência em contrato individual de trabalho. ${ }^{15}$

Daí porque pode a liberdade de trabalho sofrer, sim, restrições, desde que razoáveis, atendido o interesse público, conclusão mais de uma vez referendada pelos tribunais, ${ }^{16}$ inclusive estrangeiros. ${ }^{17}$

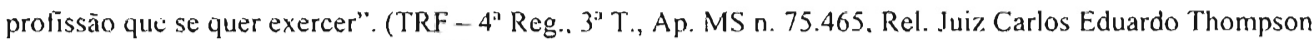
Flores Lenz, julg. em 12.03.02 in DJU de 03.04.02, p. 543) e "A liberdade para o livre exercicio de qualquer trabalho insculpida no artigo $5^{\circ}$, XIII, da Constituição Federal não é absoluta..".(TRF - $4^{\mathrm{a}}$ Reg.. $3^{\mathrm{a}}$ T., Ap. MS n. 73.347. Rel. Juiza Luiza Dias Cassales, julg. em 21.08.01 in DJU de 12.09.01).

12 C. DORIA, A. de Sampaio. Principios constitucionais. São Paulo: São Paulo Editora, 1926. p. 124.

13 Preceitua o United States Code: "Every contract, combination in the form of trust or othenvise, or conspiracy. in restraint of trade or commerce among the several States, or with foreign nations, is declared 10 be illegal. Every person who shali make any contract or engage in any combination or conspiracy hereby declared to be illegal shall be deemed guilty of a felony. and, on conviction thereof, shall he pumished by: fine not exceeding $\$ 10,000,000$ if a corporation. or. if any other person, $\$ 350,000$, or by imprisonment not exceeding three years, or by both said punishments, in the discretion of the court" (Titulo 15, Seção 1).

is Sobre o tema, amplamente, BLAKE. Harlan M. Employee agreements not to compete. Harvard Law Review. v. 73. n. 4. p. 625 e segs. February 1960. Para a indicação dos antecedents históricos da cláusula de nãoconcorrência no direito anglo-americano, cf. CALLAHAN, Maurcen B. Pos-employment restraint agreements: a reassessment. University of Chicago Law Review, n. 52, p. 707 e segs.

1: Les clauses restrictives de la liberto d'emploi dans li contrat de travail des techniciens el employés de l'industrie el du cummerce. Revue Internationale du travail. (jenève, v. XIX, n. I, p. 423 e segs, janvier 1929.

16. -Administrativo. Livre exercicio profissional (CF-88, art.5, XIII). Limites. Advocacia. Servidor policial. 1. A regra constitucional comporta limitcs. 2. Proibido ao policial exercer a advocacia. 3. Apelação improvida".(TRF - 4² Reg.. $3^{3}$ T., Proc. n. 9204065630. Rel. Juiz Fábio Rosa, julg. em 10.08.93 in DIU de 15.09.93, p. 37.880); "Mesmo sendo livre o exercício de qualquer trabalho, a Constituição Federal admitc que o ordenamento jurídico infraconstitucional faça restrições de acordo com a natureza da profissão que se quer exercer" (TRF - 4a Reg., 3 $3^{\mathrm{a}}$ T. AI n. 80.115, Rel. Juiza Marga Inge Barth Tessler. julg. em 25.09.01 in DJU de 10.10 .01 , p. 830) e "Além do requisito de qualificação profissional (art. 5\%, XIII. da Constituição), porque năo estabelecido de forma exclusiva, uutros são impostos ao livre exercicio das profissões regulamentadas, $\mathrm{cm}$ atençào aos principios genéricos que condicionam o exercício da liberdade".(TRF - $\mathrm{I}^{\mathrm{x}}$ Reg., 5 T.. Ap. MS n. 01000869450, Rel. Juiz João Batista Moreira, julg. em 22.10.01 in DJU de 28.09.01, p. 99). Ainda no mesmo sentido, cf. TRF $-4^{*}$ Reg., $3^{2}$ T., Arg. Inconst. na Ap. MS n. 77.990. Rel. Juiza Marga Inge Barth Tesster, julg. em 28.08.03 in DJU de 01.10.03, p. 338.

1: Fm decisão de 1913, a Curte de Apelaçăo inglesa assinalou, no julgamento do caso Mason v Provident Clorhing \& Supply Co Lid. que o interesse público é que pennite reconciliar "the apparent antagonism 
De outro lado, a possibilidade de restrição negociada da liberdade de trabalho, por meio de cláusula ajustada entre empregado e empregador, acha-se prevista mesmo em sistemas jurídicos em que expressamente assegurado o livre exercício de trabalho. Tal o caso do Direito português, no qual a regra do art. $58^{\circ}, \mathrm{n}$. 1, da Constituição, ${ }^{18}$ garantidora da liberdade de trabalho e de profissão, ${ }^{19}$ convive com o pacto de não-concorrência, mencionado no art. $146^{\circ}$, do Código do Trabalho, e do Direito espanhol, em que a Constituição também consagra o direito ao trabalho ${ }^{20}$ e a legislação ordinária prevê a restrição pós-contratual ao trabalho, consoante o art. 21, do Estatuto de los Trabajadores. ${ }^{21}$

Por fim, restrições à concorrência caracterizam desdobramento da imposição, que pesa sobre os contratantes, de observância do princípio da boa-fé objetiva, do qual se extraem, inclusive no campo das relações de trabalho, obrigações exigiveis não apenas no momento da conclusão do contrato e durante a sua execução - segundo dá a

between the right to bargain and the right to work... by the establishment of a principle and a limit of general application" Já a Alta Corte da Ausırália, no caso Lindner v. Murdock's garage, de 1950, (83 CLR 628), registrou: "Where an employee has access 10 trade secrets or other confidential information he may be restrained by agreement from communicating those secrets or such information to other persons, and particularly to competitors in trade sith his employer. Again. an employee who is bronght into personal contad with the customers of his employer may hy agreement effectively bind himself 10 abstain after his term of service has been completed from soliciting the customers of his former employer. In these cases the covenant in restraint of trade is not a covenant against mere competition but is a covenam directed 10 securing a reasonable protection of the business interest of the employer. and in the circumstances is not unjust to the employee. The interest which can validly be protected is the trade connection. the goodwill of the business of the employer"

is A norma está assim redigida: "Todos têm direito ao trabalho".

10 MIRANDA, Jorge. Mamual de direito constinucional. Coimbra: Coimbra Editora, 1998. tomo IV, ns. 112 e segs.. p. 432 e segs.

$20 \mathrm{O}$ art. 35. n. I, da Constituição espanhola contém a seguinte regra: "Todos los españoles tienen el deber de trabajar y el derecho al trabajo, a la libre elección de profesión u oficio. a la promoción a través del trabajo y a una remuneración suficiente para satisfacer sus necesidades y las de su familia, sin que en ningun caso pueda hacerse discriminación por razón de sexo"

" Note-se, inclusive, que atualmente a liberdade de trabalho está explicitada na Carta dos Direitos Fundamentais da União Européia, em cujo art. $15^{\circ}$ preceitua-se: "Liberdade profissional e direito de trabalhar 1. Todas as pessoas têm o direito de trabalhar e de exercer uma profissão livremente escolhida ou aceite. 2. Todos os cidadãos da União têm a liberdade de procurar emprego, de Irabalhar, de se estabelecer ou de prestar serviços em qualquer Estado-Membro" Bem se vê que a sentença de 18 de julho de 1973, da Corte Suprema de Justiça da Colômbia. que considerou inexequïivel. porque inconstitucional, a parte final do art. 44, do Código Substantivo do Trabalho, no ponto em que admitia a estipulação de cláusula de nãoconcorència "hasta por un año cuando se trate de trabajadorés técnicos, industriales o ugricolas", não se justifica. Assinalaram, aliás, os juizes que na ocasião ficaram vencidos: "El articulo sub-judice consagra la llamada "cláusula de no concurrencia". admitida por la muyor parte de las legislaciones del mundo y explicada por los autores de Derecho Laboral por razones eticas de leallad hacia el parrono a quien se prestan los servicios. Por eso el precepto acusado admite la pusibilidad de estipular el abstenerse de "prestar sus servicios a los competidores de su patrono". y iste concepto de leallad ni es descueto. $n i$ extraño al régimen constitucional colombiano que en el artículo 32 de la Constitucion "garantiza la libertad de empresa y iniciativa privada dentro de los limites dal bien comin" 
entender a letra imperfeita do art. 422, do Código Civil brasileiro -, como também antes, na fase pré-negocial, e mesmo após, na fasc pós-contratual.?

Em síntese, a omissão da legislação trabalhista brasileira na disciplina da não-concorrência pós-contratual não torna inválida, em principio, tal previsão, quando regularmente pactuada, não sendo a restrição, por si só, inconstitucional, conforme já teve opurtunidade de concluir, em pelo menos duas diferentes ocasiões, a jurisprudência, ${ }^{23}$ em diretriz igualmente referendada pela doutrina. ${ }^{24}$

Pode o empregador, conseqüentemente, contratar a limitação da atividade do empregado para o período subseqüente à extinção do vínculo contratual. ressalvadas. apenas, hipóteses em que existente expressa previsão legal em sentido diverso. como é o caso, para citar somente um exemplo, do empregado contratado por empresa de trabalho temporário, favorecido pela previsão do art. 11, § único, da I ei n. 6.019, verbis: "Será nula de pleno direito qualquer cláusula de reserva, proibindo a contratação do trabalhador pela empresa tomadora ou cliente ao fim do prazo em que tunha sido colocado à sua disposição pela empresa de trabalho temporário"

\section{Pressupostos e limites da cláusula de não-concorrência}

É evidente que afirmar a licitude da cláusula de não-concorrência. como se fez. no item anterior, não implica validar qualquer espécie de pactuação. Mesmo que se reconheça o direito de limitar-se a ulterior atividade do empregado, esse direito não comporta - novamente como qualquer outro direito - exercício desmedido, sob pina de, só por isso, caracterizar-se abuso. bastante ao reconhecimento da ocorrência de ilícito (Código Civil, art. 187). A restrição à liberdade de trabalho tem de satisfazer legítimo

22 Cf., a propósito. Eduardo BARACAT, Milléo A boa-fé no direito individual do rabalho. São Paulo: LTr, 2003. p. 265. c ARAÚJO. Francisco Rossal de. A hoa-fé no contralo de emprego. São Paulo: LTr. 1996. p. 264 .

23 "Dircito ao trubalho. Cerceamento. Inexiste nulidade e tampouco cerceamento de trabalho na clausula contratual que impeça o empregado de, durante certo tempo apos a rescisão, trabalhar para a empresa concorrente, quando o pacto assegura a devida complementação na cventualidade de redução salarial em trabalho para empresa não-concorrente".(TRT - $2^{a}$ Reg., $7^{a}$ T., Ac. n. 02880177116 , julg. 29.08.88 in DJ de 16.09.88, Proc. n. 02870094455, Rcl. Juiza Wilma Nogueira de Araujo Vaz da Silva) e "Cláusula de nãoconcorrència. Validade. A cláusula de não-concorrência foi estabelecida por tempo razoável e houve pagamento de indenização. Logo, está dentro dos principios da razoabilidade e da proporcionalidade. É, portanto, considerada válida. Não há dano moral a ser reparado“.(TRT - $2^{\mathrm{u}}$ Reg., $3^{\mathrm{a}}$ T.. RO n. 02243200038102009, Rel. Juiz Sérgio Pinto Martins in DOE de 08.06.2004).

24 CESARINO JÚNIOR, A. F. e CARDONE, Marly. Direito social, São Paulo, LTr, 1993. v. I, p. 164, MARTINS. Sergio Pinto. Direito do Trahalho. São Paulo, Allas, 2003. p. 136, e BELTRAN, Ari Possidonio. A cláusula de não-concorrència no direito do trabalho. Revista do Adrogado. São Paulo, Associação dos Advogados de São Paulo. n. 54, p. 67, dez. 1998. Na doutrina mais antiga, examinado o problema soh o prisma da liberdade de trabalho, cf. MENDONÇA, J. X. ('arvalho de. Tratado de Direito Commercial Brasileiro. Rio de lanciro: Freitas Bastos, 1933, v. II, L.ivro I. n. 462, p. 449. 
interesse do empregador e não se apresentar de forma desarrazoada. Assim, admitido o cabimento, em tese, da cláusula de não-concorrência em contrato de trabalho, torna-se imperioso determinar os parâmetros a observar para que o ajuste não seja havido por exorbitante. diante dos termos da pactuação.

a) necessidade de restrição

Em primeiro lugar, é preciso que se justifique a restrição, objetivamente necessária, como ocorre, ademais, com toda limitação à liberdade, conforme notou Pontes de Miranda. ${ }^{25}$ Compreende-se. A interferência na liberdade de trabalho do empregado somente é válida quando destinada a satisfazer relevante e legitimo interesse do empregador. ${ }^{26}$ Consoante realçado pela doutrina norte-americana, "if the employee learns no secrets and does not have any contact with the costumers of the employer there is no reason for enforcing... a restrictive covenant and the covenant should be struck down as imposing un undue hurdship upon the person restricted" 27

Trata-se, aliás, de requisito invariavelmente presente nas diversas legislações que disciplinam expressamente a cláusula de não-concorrência, manifestandose de forma variada. No Direito português, por exemplo, a cláusula de não-concorrência somente pode ser estabelecida em relação a "actividade cujo exercício possa efectivamente causar prejuizo ao empregador" 28 De modo bastante semelhante, o Estatuto de los Trabajadores espanhol condiciona a validade do pacto de no competencia a que "el empresario tenga un efectivo interés industrial o comercial en cllo" 29

Para avaliar a legitimidade da cláusula de não-concorrência é preciso. portanto. considerar a natureza da atividade atribuída ao empregado, o conhecimento que ele por conta disso adquire e o uso que poderá de tal conhecimento fazer após o término do contrato de trabalho. Restriçâo que, imposta a trabalhador manual, sem conhecimento especializado, responsável por tarefas rotineiras, não se admite, pode ser válida quando dirigida a empregado de alta formação. encarregado do desenvolvimento de novos produtos ou com acesso a dados sigilosos de custos, de mercado ou de outra espécie, que sejam istratégicos.

25 Comentários à Constituição de 1967. Rio de Janeiro: Forense, 1987. tomo V. p. 545.

26 Cf. CORRADO, Renato. Il lavoratore nell'organizzazione dell'impresa. In: Nuove tratruto di dirillo del lavoro. Padova: CEDAM. 1971, v. II, p. 267. ALONSO OLEA, Manuel. Derecho del rabajo. Madrid: Universidade de Madrid, 1974. p. 154, e VATINET, Raymonde. Les principes mis en oeuvre par la jurisprudence relative aux clauses de non-concurrance en droit du travail. Droit Social, p. 536. juin 1998. CALAMARI. John D.; PERILLO, Joseph M. The law of contracrs. Minnesota: West Publishing, 1970, 357, p. 542. Fm jurisprudência, cf. United States Court of Appeals for the Seventh Circuit em The Osler Institulc, Inc. v. Lois Forde (n. 02-3441), decisão de 26.03.03.

29 Art. 21, n. 2. "a" 
Năo se deve, no enfrentamento da questão, adotar visão reducionista, considerando apenas parcialmente o contexto em que executado o contrato de trabalho. Tampouco proposições genéricas ou abstratas são adequadas, porque mesmo o conhecimento de certos aspectos importantes do negócio algumas vezes não se mostra por conta das peculiaridades de cada atividade e do uso que da informação se pode fazer relevante a ponto de justificar restrição posterior au trabalho do empregado. Conforme observado pela Alta Corte da Austrália, em julgamento envolvendo discussão sobre licitude de cláusula de não-concorrência inserida em contrato de trabalho, "each case must be considered in relation to its own circumstances" 30 A clientela, por exemplo, constitui, em regra, "a particulary sensitive aspect of the businesses" 31 tanto que tutelada pela legislação, ${ }^{32}$ inclusive em relação a agentes públicos. ${ }^{33}$ Mas o mero contato com os clientes do empregador, propiciado ao empregado por força do contrato de trabalho, nem sempre basta para legitimar cláusula de não-concorrência. ${ }^{34}$ Algumas vezes a informação não adquire relevância particular, diante do escasso uso que dela pode fazer o empregado. ${ }^{35}$ É o que se passa com o caixa de supermercado, que conhece os clientes do estabelecimento, mas pouco benefício econômico consegue extrair de tal informação. Daí o acerto da regra do art. 340, n. 1, do Código suíço das obrigações, ao condicionar a imposição de cláusula de não-concorrência à possibilidade de causar o empregado prejuízo sensivel ao empregador: "I a prohibition de faire concurrence n'est valable que si les rapports de travail permettent au travailleur d'avoir connaissance de la clientèle ou de secrets de fabrication ou d'affaires de l'employeur et si l'utilisation de ces renseignements est de nature à causer à l'employeur un préjudice sensible"

A cláusula de não-concorrência tem de especificar as atividades restringidas, indicando os limites objetivos da obrigação imposta ao empregado, como deixa expresso o art. 2.125 , do Codice Civile italiano. ${ }^{36}$ Trata-se de requisito substancial

30 Caso L.indner v. Murdock's gurage, de 1950 (83 CLR 628).

31 BLAKE. Harlan M. Employee agreements not to compete cil., p. 653.

32 Cf. art. 195. inciso III, da Lei brasileira n. 9.279. que inclui, no conceito do crime de concorrência desleal, a conduta consistente $\mathrm{im}$, de modo fraudulento, "desviar, em proveito próprio ou atheio, clientela de outrem"

33 Preceilua o Decreto n. 4.552/02, que estabelece o Regulamento da Inspeção do Trabalho: "Art. 35. É vedado aos Auditores-Fiscais do Trabalho e aos Agentes de Higiene e Segurança do Trabalho: I - revelar, sob pena de responsabilidade, mesmo na hipólese de afastamento do cargo, os segredos de fabricação ou comércio, bem como os processos de exploraçào de que tenham tido conhecimento no exercicio de suas funções; II revelar informações obtidas em decortência do exercicio das suas competẻncias;...".

34 Cf. GAVALDA, Natacha. Les critères de validité des clauses de non-concurrance en droit du travail. Droit Social, n. 6, p. 586, juin 1999.

35 Novamente BLAKF, Harlan M. Empioyee agreements not 10 compete cit, p. 663.

36 A norma tem a seguinte redação: "Il palto con il quale si limita lo svolgimento dell'attività del prestatore di lavoro, per il tempo successivo alla cessazione del contrallo. i mullo se non risulta da atto scritto (2725), se non i pattuito un corrispettivo a favore del prestator' di lavoro e se il vincolo non é contemuto entro determinati limiti di oggetto. di tempo e di luogo" 
de validade do ajuste, cuja falta torna-o nulo, até porque não se admite restrição genérica, indeterminada, abrangendo todo e qualquer trabalho. Apenas a restrição necessária pode ser mantida. ${ }^{37} \mathrm{O}$ químico que tenha trabalhado para empresa de produtos de beleza, no desenvolvimento de determinado perfume, em princípio não está impedido de exercer a sua profissão em empresa de outro ramo de atividade como, por exemplo, indústria automotiva.

\section{b) limite espacial da restrição}

De outra parte, a restrição à atividade do empregado, em harmonia com o requisito da necessidade, antes indicado, há de ser limitada espacialmente, segundo as reais exigências do caso, salvo $\mathrm{cm}$ circunstâncias excepcionais, nas quais tal limitação revela-se inviável. Informação que somente em reduzida área tem significado - como volume de passageiros transportados em linhas municipais de ônibus, por exemplo - não permite cláusula de não-concorrência no âmbito de uma larga região e muito menos de todo o país. Dai a disposição encontrada no art. $65, \S 2^{\circ}$. da lei belga relativa aos contratos de trabalho, de 3 de julho de 1978, a condicionar a validade de qualquer cláusula de nãoconcorrência a que fique ela "géographiquement limitée aux licux où l'ouvrier peut faire une concurrence réelle à l'employeur, en considérant la nature de l'entreprise et son rayon d'action" Previsão semelhante existe ainda em várias legislações estaduais norteamericanas. $^{38}$

A imposição de limite espacial à restrição - que se compreende perfeitamente - não significa, todavia, exclusão peremptória de cláusula com âmbito de

37 WYLER, Rémy. Droit du rravail. Beme: Staempfli, 2002. p. 453.

38 O Dakota do Norte Century Code, por exemplo, no Capitulo 9-8, a respeito de "unlawful and voidable contracts", no item 06, dispõe: "Every contract by which anyone is restrained from exercising a lawful profession, trade. or business of any kind is to that extent void, except: 1 . One who sells the goodwill of a business may agree with the buyer to refrain from carrying on a similar business within a specified county. city, or a part of either...". Em termos muito semelhantes, em Oklahoma, nos State Statutes, \$15-217 e \$15218 lê-se, respectivamente: "Fvery contract by which any one is restrained from exercising a lawful profession, trade or business of any kind. otherwise than as provided by Sections 218 and 219 of this title, is 10 that cxtent void" e "One who sells the goodwill of a business may agree with the buyer to refrain from carrying on a similar business within a specified county and any county or counties contiguous therelo, or a specified city or town or any part thereof, so long as the buyer, or any person deriving title to the goodwill from him carries on a like business therein. Provided, that any such agreement which is otherwise lawful but which exceeds the territorial limitations specified by this section may be deemed valid, but only within the county comprising the primary place of the conduct of the subject busincss and within any counties contiguous thereto" Já o Business \& Commerce Code do Estado do Texas preceitua: "§ 15.50. Criteria for enforceability of covenants not 10 compete. (a) Notwithstanding Section 15.05 of this code, and subject 10 any applicable provision of Subsection (b), a covenant not to compete is enforceable if it is ancillary to or parl of un utherwise enforceable agreement at the time the agreement is made to the extent that it contains limitations as to time, geographical area, and scope of activity to be restrained that are reasonuble and do not impose a greater restraint than is necessary to protect the goodwill or other business interest of the promisee". 
validade superior ao território nacional, diversamente do que. agora de modo inaceitável, deficiente e em completo desacurdo com a realidade, preceitua a mesma lei belga antes referida." Há quase mcio século já sc advertia para o fato de que "markéts and competition are increasingly national. even international, in scope" ${ }^{40}$ Ademais, em sc tratando de informação, restrições territoriais fazem pouco ou nenhum sentido. Como já se observou com todo acerto, "information, unlike customers, is highly mobile" "Por fim, a produção mesmo, por conta das diferentes possibilidades técnicas, realiza-se hoje com enorme facilidade em diferentes partes do mundo e desloca-se, de um lado para outro, com grande rapidez. O notável desenvolvimento da indústria de tecnologia de informação na região de Bangalore, na Índia, ocorrido em curto espaço de tempo, é por demais eloqüente e dispensa outras referências. Nesse caso específico de Bangalore, como ressaltado em estudo da Organização Internacional do Trabalho, "il suffit d'appuyer sur une touche pour que le 'produit' à savoir les logiciels, soit livre n'importe où dans le monde, en temps réel ${ }^{2}$ Rustringir, em tal contexto, a eficácia de cláusula de nãoconcorrência ao âmbito do território nacional não se justifica, e faria com que se tornasse muito fácil burlar a limitação, comprometendo a legítima tutela da informação, o que não se admite. Deve-se. pois, aceitar, ao menos em tese, restrição territorialmente mais ampla. caso, diante das circunstâncias, seja ela realmente necessária. ${ }^{43}$

\section{c) limite temporal da restrição}

Outro aspecto a considerar é o relacionado com o tempo de duração da obrigação de não-concorrência. Restrição permanente ou mesmo indefinida afigura-se. seja qual for a atividade considerada ou o empregado envolvido. ilícita. conclusão a que se chega sem nenhuma dificuldade. ${ }^{44}$ Cerceia, de modo desmedido, a liberdade de trabalho do empregado. Ademais, restrição temporalmente ilimitada compromete o próprio desenvolvimento econômico e "o livre progresso", 45 o que não se concebe. Finalmente, o passar do tempo faz com que as informações e o conhecimento adquiridos pelo

39 Trata-se. ainda, do mesmo art. $65, \S 2$ ", em que se ressalta que a cláusula de nào-concorrência "ne peut en aucun cas s'étendre au-dela du territoire national"

40 BLAKE, Harlan M. Lmployee agreements not to compete. cit., p. 675.

4) BLAKE, Harlan M. Eimployee agreements not to compere. cit., p. 679.

42 Le travail dans le monde. Genève: Bureau International du Travail, 1997. p. 92.

4 No mesmo sentido. relativamente à abrangência da tutela penal do segredo industrial, FEKETE, Elisabeth Kasznar. O regime juridico do segredo de indistria e comércio no direito brasilciro. Rio de Janeiro: Forense, 2003. p. 292-293.

4t Surpreendentemente, porém, a Corte de Apelação inglesa, ao decidir, em 1997, o caso Dentmaster. (UK) Limited :. Patrick Francis Kent, afirmou, considerando as circunstâncias particulares do caso, que não via "nothing illogical in the absence of a backward temporal limit on the employee's dealings with...customers" A conclusão é inaceitável e não há especiais razões que legitimem tão severa restrição.

45 MENDONCA, J. X. Carralho de. Tratado de Direito (ommercial Brasileiro, cit., n. 462, p. 449 
trabalhador. quando da execução do desfeito contrato de trabalho, se desatualizem, percam importância e. em conseqüência, deixem de justificar restrição à sua ulterior atividade prufissional. Pense-se no custo de produção. Trata-se, sem sombra de dúvida, de dado estratégico. Utilizado de modo impróprio pode dar margem a concorrência desleal entre empresas. Por isso mesmo é, não poucas vezes, protegido com especial cuidado, tal como o segredo do negócio. Quc importa, porém, conhecer os custos de produção de mercadorias que nem mais existem ou que, passado certo tempo, são produzidas de outro modo, com insumos diversos e preços completamente diferentes? Muito pouco ou, talvez, quase nada.

Várias legislações fixam os prazos máximos de duração da obrigação de não-concorrència. No Código suiço das obrigações, por exemplo, estabeleceu-se o máximo de três anos. ressalvadas situações excepcionais, não-definidas pelo legislador, em que su pode adotar lapso mais longo de tempo, sem limite pré-estabelecido. ${ }^{46} \mathrm{O}$ Código do Trabalho de Portugal segue critério parcialmente semelhante. Prevê o prazo máximo de dois anos," mas admite a sua ampliação para até trîs anos, "tratando-se de trabalhador afecto ao exercicio de actividades cuja natureza suponha especial relação de confiança ou com acesso a informação particularmentc sensivel no plano da concorrência" ${ }^{18}$ A lei belga de 3 de julho de 1978, já lembrada, impõe prazo mais exíguo, de no máximo doze meses, sem possibilidade de variação. ${ }^{49}$ Outras legislações adotam distintos prazos máximos, de acordo com a qualificação do empregado. Nessa linha, o Código Civil italiano fixa o máximo de cinco anos para os dirigentes e de três anos para os demais empregados. ${ }^{50}$ Já o Estatuto de los Trabajadores da Fispanha adota prazo máximo inferior, dois anos para os técnicos e seis meses para os empregados comuns. ${ }^{51}$ Nos EUA não existe prazo mencionado em lei para a restrição, mas a doutrina sublinha que os tribunais raramınte inıalidam ajustes com prazo de vários meses ou mesmo de um ano, "and even longer restraints are often enforced" 52

Da omissão da legislação brasileira, já antes assinalada, não se pode inferir inexistência de limite temporal à obrigação de não-concorrência, até porque restrição permanente ou indefinida, como foi dito, é evidentemente ilcgal. Significa. apenas, que a validade dos limites temporais pactuados fica sujeita a revisão judicial segundo parâmetros mais fluídos, não-estabelecidos previamente pelo legislador, afastada -

\footnotetext{
Art. $340, a$, n. 1.

Art. $146^{\circ}$, n. 2.

Art. $146^{\circ}$, n. 5 .

Art. $65, \S 2^{\circ}, 3^{\circ}$.

Art. 2.125.

An. 21.

52 BLAKE, Harlan M. Emplovee agreements not to compete. cit., p. 677.
} 
sublinhe-se - a aplicação analógica do prazo máximo mencionado no art. 445. caput, da CLT, que não guarda nenhuma relação com o caso.

A restrição, estabelccida por mcio da cláusula de não-concorrência, pode iniciar-se logo após o término do contrato de trabalho ou, também, passado ccrto prazo. Algumas vezes a atividade econômica desenvolve-se de modo cíclico, com maior intensidade em certos periodos, de modo a fazer com que a não-concorrência tenha mais importância em momentos mais avançados no tempo, sem que seja necessária no periodo imediatamente subseqüente à rescisão contratual. Não se deve considerar necessariamente inválida, pois, cláusula que. sem limitar a atividade nos seis meses logo após a rescisão do contrato de trabalho, a proiba no período compreendido entre seis meses e um ano após a dispensa do empregado.

\section{Compensação pela não-concorrência}

No Direito francês não existe, segundo doutrina e jurisprudência, obrigação de contrapartida a cargo do empregador, para a obrigação de não-concorrência imposta ao empregado. ${ }^{53}$ Afirma-sc, em conseqüência, a possibilidade de ser unilateral a pactuação. Trata-se de conclusão que, mesmo diante do silêncio da legislação hrasileira, não há como acolher.

A exigência de contraprestação constitui, na verdade. a regra no direito comparado. ('onsta, como requisito de validade da cláusula de não-concorrência, no Código de Trabalho de Portugal, ${ }^{54}$ na legislação belga, ${ }^{55}$ no Estatuto de los Trabajadores da Espanha ${ }^{56}$ e no Codice Civile italiano. ${ }^{57}$ No Brasil, essa exigência resulta não somente da aplicação do disposto no art. $8^{\circ}$. caput, da CLT, que erige o direito comparado em fonte de integração de lacunas da legislação, como também da nccessidade de observar-se mínimo equilíbrio entre a obrigação imposta ao empregado e a contrapartida que se lhe oferece, como desdohramento da proibição de lesão. ${ }^{58}$ agora positivada no art. 157 , do Código Civil. Pode a exigência, ainda. ser inferida da limitação imposta à liberdade de contratar pela regra do art. 421, do Código Civil. Logo, a onerosidade caracteriza

53 GAUDU, François; VATINE T, Raymond. Les contrats du ravail. Paris: LGDJ, 2001. n. 317, p. 268. GOFF. Jacques le. Droit du travail et société. Les relations individuelles de travail. Paris: Presses Universitaires de Rennes, 2001. p. 305, e, ainda, Mémento pratique LEFEBVRE, Francis. Levallois. Éditions Francis Lefubvre, 1995, n. 2.789. p. 281.

54 Art. $146^{\circ}$. n. 2, alinea " $\mathrm{c}$ "

ss Lei de 3 de julho de 1978. Art. 65. $\$ 2^{\circ} .4^{\circ}$

56 Art. 21, n. 2, aliena "b".

57 Art. 2.125

58 A propósito, PEREIRA. Caio Mário da Silva. Lesão nos contratos bilaterais. Rio de Janciro: Forense, 1949. n. 77.p. 140. 
condição de validade do ajuste, como assinalado pela doutrina italiana, de modo a repelirse pacto gratuito. ${ }^{59}$

A compensação há de ser proporcional à restrição imposta. Quanto mais ampla a limitação - quer do ponto de vista do objeto, quer do ponto de vista temporal, quer, ainda, do ponto de vista espacial maior deve ser a compensação e vice-versa. $O$ valor da compensação não está vinculado, portanto, ao montante da remuneração recebida pelo empregado durante a vigência do contrato, ao contrário do que já se pretendeu. ${ }^{00} \mathrm{Se}$ a restrição ao trabalho é pouco abrangente, não se justifica imposição de pagamento correspondente ao salário antes recebido. ${ }^{01} \mathrm{O}$ importante é que não exista desequilíbrio entre as obrigações das partes.

Não há razão para se exigir necessariamente pagamento mensal da compensação. Nada obsta, por exemplo, a liquidação do valor de uma só vecz ou em algumas parcelas, seja no momento em que contratada a restrição, seja após curto prazo. Mas o prazo de pagamento deverá, ser adequado, como a própria compensação. Não se admite que todo o pagamento seja feito somente depois de esgotado o período de restrição. Seria impor ao empregado obrigação muito onerosa em troca de contrapartida desequilibrada. Tampouco se concebe pagamento feito durante a vigência do contrato, juntamente com o salário, em percentual da remuneração ajustada. A prática, além de fazer com que o valor da indenização se torne aleatório, ficando na dependência da duração do próprio contrato, abre espaço para fraude. consistente em transformar-se pagamento por trabalho em compensação pela obrigação de não-concorrência. Trata-se, por isso mesmo, de procedimento repelido pela jurisprudência italiana. ${ }^{62}$

Nenhuma restrição existe quanto a fazer-se o pagamento não em dinheiro, mas sim em utilidades. O que se deve sempre avaliar é o equilíbrio do que se dá em relação ao sacrifício que se impõe. Se se atribui ao empregado bem com significativo valor, compativel com a extensão da restrição imposta, acha-se satisfeita a exigência.

O crédito conferido ao empregado, por conta da restrição de trabalho, constitui, sem sombra de dúvida, parcela trabalhista. Fica sujeito - importante notar o ponto - ao regime legal de proteção conferido a essas parcelas, ${ }^{63}$ sofrendo atualização, a partir de seu vencimento. segundo os critérios do art. 39, da Lei n. 8.177.

59 CORRADO, Renato. Trattato di diritto del lavoro. Torino: UTET, 1969. volume terzo, n. 118, p. 277

${ }^{60}$ MARTINS, Sergio Pinto. Direito do Trabalho. cit., p. 138.

${ }_{61}$ QUINTAS. Paula; QUINAS. Helder. Código do Trabalho anotado e comentado. Coimbra: Almedina. 2004. p. 387.

62 CORRADO, Renato. Il lavoralore neli'organizzazione dell 'impresa, cit. p. 269-270.

63 Assim, em face do direito português, FERNANDES, Antonio Lemos Monteiro. Direito do trabalho. Almedina: Coimbra. 1999. p. 592, e em face do Direito francês, VATINET, Raymonde. Les principes mis en neuvre par la jurisprudence relative aux clauses de non-concurrance en droit du travail. cit., p. 536. 
Revestc-se o crédito conferido ao empregado, outrossim, de natureza indenizatória, como explicitado em alguns sistemas jurídicos. ${ }^{\text {ot }}$ Não se remunera ubrigação de não-fazer, consistente em não-exercer determinada atividadı Indeniza-se, isso sim, a limitação à liberdade de trabalho. ${ }^{65}$ Não constitui, em conseqüência, base de incidência de contribuições previdenciárias ou imposto de renda, ${ }^{\text {no }}$ à semelhança dos valores conferidos em programas de incentivo à rescisão de contrato de trabalho. ${ }^{67}$

\section{Forma}

A cláusula de não-concorrência é estabelecida normalmente por escrito. Trata-se, inclusive, da forma ideal, porque torna mais simples a comprovação do ajuste e mais fácil a identificação dos seus limites e contornos. Cuida-se, porém, de solenidade essencial, nus termos do art. 166, inciso V. do Código Civil?

Em vários sistemas jurídicos - como, por exemplo, no Direito português, ${ }^{68}$ no Direito italiano ${ }^{69}$ e no Direito belga ${ }^{70}$ - a forma escrita é da essência do pacto de nãoconcorrência. No Direito suíço, a partir da regra do art. 340, n. 1, 1, do Código das obrigações, entende-se que nem mesmo a referência indireta à obrigação de nãoconcorrência, feita por meio de reenvio no contrato escrito de trabalho, a texto contido $\mathrm{cm}$ regulamento de empresa ou a manual de pessoal, basta para satisfazer a exigência legal." No Direito brasileiro, todavia, a exigência de forma especial, para a validade das declarações de vontade, depende de previsão expressa, nos termos do art. 107, do Código Civil. E sendo omissa a legislação, no tocante à cláusula de não-concorrência, torna-se não-obrigatória a forma escrita. conclusão referendada pela regra do art. 442, da CLT, e não prejudicada pelo disposto no art. 29, caput, da CLT, preceito que não cria requisito de validade para toda e qualquer condição especial de trabalho.

64 A lei belga de 3 de julho de 1978 , em seu art. $65, \S 2^{\circ} .4^{\circ}$, designa o pagamento devido pelo empregador por conta de cláusula de não-concorrência como "indemnité compensatoire"

65 No mesmo sentido, OLIVEIRA. Oris. de A exchusão de concorrência no contrato de trabalho. São Paulo: s. e. p. (tese), s. d. p.. p. 256, e MARTINS, Sergio Pinto. Direito do Trabalho. cir.. p. 139.

66 Em sentido contrário, em face do Direito francês, alirmando que o pagamento efetuado pelu empregador $\mathrm{cm}$ compensação à não-concorrència "doit donner lieu au paiment de cotisations sociales", Raymonde Vatinet, Les principes mis en oeuve par la jurisprudence relative aux clauses de non-concurrance en drou du ravail cit., p. 536.

${ }^{67}$ Cf., relativamente ao imposto de renda. Súmula 215 , do Superior Tribunal de Justça e, a propósito da contribuição previdenciária, art. 214. \$ $9^{n}$, inciso V, alinea "e", do Decreto n. 3.408/99.

68 Código do Trabalho, art. $146^{\circ}$, n. 2. aliena "a"

69 Codice Civile, art. 2125.

70 Lei de 3 de julho de 1978, art. 65.

"I W LER, Rèmy. Droil du travail cit., p.44s. 
De cláusula implicita de não-concorrência não se deve cogitar, todavia. Como assinalado pela Corte de Apelação inglesa, no já lembrado julgamento proferido no caso Mason v Provident Clothing \& Supply Co Lid, "the public interest... is always upor the side of liberty, including the liherty to exercise one's powers or to earn a livelihood..." A ausência de previsão de limite à liberdade de trabalho implica. portanic. inexistência de restrição especifica.

Podem os limites uu as condições gerais para a celebração de pacto de nãoconcorrência estar previstos em acurdo coletivo de trabalho ou em convenção coletiva de trabalho. É lícito, por exemplo, que a norma coletiva estabeleça padrões mínimos relacionados com os direitos devidos ao empregado por conta da restrição ao trabalho e com o âmbito territorial ou periodo máximo de tempo para essa restrição. Não se afasta nem mesmo que a norma coletiva simplesmente próba restrição contratual à concorrência. Em qualquer caso, ficam empregado e empregador sujeitos às condições impostas coletivamente, admitida contratação individual apenas dentro dos respectivos limites, na forma dos arts. 444, e 619, da CLT. Não cabe, no entanto, estabelecer, por meio de negociação coletiva, diretamente e sem a adesão individual do empregado, cláusula geral de não-concorrência. A hipótese, aceita no Direito francês, condicionada a simples ciência e não-concordância * do empregado, ${ }^{72}$ envolveria contratação coletiva in pejus. não admitida pelo legislador brasileiro, salvo em casos taxativamente determinados. $^{73}$

O fato de não se haver pactuado restrição à concorrência para depois da extinção do contrato de trabalho não significa, contudo, esteja o empregado livre para, depois de deixar o emprego, praticar quaisquer atos ou exercer, sem nenhum constrangimento, qualquer trabalho, ofício ou profissão, valendo-se, inclusive, dos conhecimentos sigilosos auferidos de seu antigo empregador. Significa, apenas, ausência de limites especiais, adicionais e específicos ao trabalho, o que não elide a aplicação de outros limites, ${ }^{74}$ previstos no Código Penal ${ }^{75}$ e na legislação sobre proteção da propriedaco industrial, notadamente no art. 195 , inciso XI, da Lei n. $9.279{ }^{76}$ bem como de limites

72 LE GOFF. Jacques. Droit du travail et société cit. p. 304. e. ainda, Mémento pratique LEJ EBVRF. Francis. cit, n. 2.786, p. 279. De modu divergente, todavia, VATINET, Raymonde. Les principes mis an oeuver par la jurisprudence relative aux clauses de non-concurrance en droit du travail. cit., p. 536.

73

Ar. incisos VI, XII e XIV, da Conslituição.

74 Cf. CAI.AMARI, John D.; PERILLO. Joseph M. The law of contracis. cit., § 357, p. 542.

75 Art. 154.

76 "Art. 195. Comete crime de concorrêrcia desleal quem:...XI - divulga, explora ou utiliza-se, sem autorização. de conhecimentos, informações ou dados confídenciais, utilizáveis na industria, comércio ou prustação de serviços, excluidos aqueles que sejam de conhecimento público ou que sejam evidentes para um técnico no assunto, a que teve acesso mediante relação contratual ou empregatícia, mesmo após o término do contrato:" 
decorrentes da obrigação geral de respeito à boa-fé contratual, ${ }^{77}$ sugundo o disposto nos arts. 187 e 422, do Código Civil.

\section{Oportunidade para a adoção da cláusula}

A cláusula de não-concorrência pode ser adotada logo no momento de celebração do contrato de trabalho, ainda que adotada a modalidade de contrato de experiência (CLT, art. 443, §2 $2^{\circ}$ aliena “c”). Essa possibilidade não costuma suscitar dificuldade. Mais delicada é, todavia, a possibilidade de adoção da cláusula após a celebração do contrato.

No Direito português, ao tempo do Decreto-Lei n. 49.408 , de 1969, o pacto de não-concorrência deveria constar obrigatoriamente do próprio contrato de trabalho. ${ }^{78}$ Não se admitia sua adoção posterior, quer no desenvolvimento da relação de trabalho, quer ao ensejo de sua extinção. ${ }^{79}$ Criticava-se, porém, a solução legislativa, a qual não levava em conta que "não há momento de maior debilidade contratual do trabalhador do que o do nascimento do vinculo" 80 A reforma empreendida no ano de 2003 acolheu parcialmente a crítica e o Código do Trabalho passou a admitir a adoção de pacto de nãoconcorrência, tanto no próprio contrato de trabalho. como no "acordo de cussação deste" ${ }^{81}$ sem considerar expressamente, todavia, o periodo de vigência do contrato.

Proibir, em termos absolutos. a adoção de cláusula de não-concorrência após a celebração do contrato de trabalho cria sérias dificuldades. Não é a solução mais indicada. Impede que se adapte a relação de emprego às novas exigências surgidas durante a prestação de serviço. No contrato celebrado com empregado admitido para exercer funções subalternas não há, em regra, nenhuma necessidade de introdução de cláusula de não-concorrência. Promovido o empregado. porém, a necessidade pode surgir. Não faz sentido vedar-se terminantemente a pactuação, que se deve considerar admissivel. $\mathrm{O}$ art. 468, da CLT, não constitui obstáculo ao ajuste, porque não impede a promoção do empregado, com atribuição de novas responsabilidades, as quais são acompanhadas, no mais das vižs, de novas condições de trabalho, e entre elas se admite esteja a obrigação de não-concorrência após a extinção do vínculo. Ressalvem-se, todavia, dois pontos.

Sobre o tema, mais amplamente, FEKETE, Elisabeth Kasznar. O regime juridico do segredo de indústria c comércio no Direito brasileiro. cit.. p. 310 e segs.

77 XAVIER, Bernardo da Gama Lobo. Curso de Direito do Trabalho. Lisboa: Verbo, 1999. p. 543.

78 Ar. $36^{\circ}$, n. 2, aliena "a"

79 FERNANDES, Antunio Lemos Monteiro. Direito do trabalho. cit., p. 592.

80 FERNANDES, António Lemos Monteiro. Direito do trabalho. cit.. p. 592.

81 Art. $146^{\circ}$, n. 2. aliena "a" 
Em primeiro lugar, e como resulta do exposto acima, admite-se a pactuação de cláusula de não-concorrência no curso do contrato de trabalho apenas quando evidenciada a relevante modificação das condições reais de trabalho, de modo que o ajuste, antes injustificável ou desnecessário, agora passe a fazer sentido. Do contrário, mantidas as mesmas condições de trabalho ou introduzidas alterações sem relação com o problema da concorrência pós-contratual, a adoção da cláusula encontra obstáculo na regra do art. 468, da CLT.

Em segundo lugar, tem o empregado sempre a prerrogativa de recusar a introdução da cláusula em seu contrato ou, mais genericamente, de não aceitar a promoção, a fim de que permaneçam as condições de trabalho originalmente contratadas. ${ }^{82}$ Ao empregador resta apenas renunciar à idéia de promover o empregado ou, então. desistir da contratação da obrigação de não-concorrência.

Não se afasta a adoção da cláusula de não-concorrência apenas ao ensejo da rescisão contratual. Suponha-se que o empregado, obrigado a permanência mínima na empresa, por força de contrato celebrado com prazo, resolva desligar-se do emprego sem motivo justificado. Pode a empresa exonerá-lo da obrigação de pagamento da indenização prevista no art. 480, da CLT, contratando, todavia, não-concorrência durante certo período, mediante compensação equilibrada. Nada há de irregular no ajuste.

A mesma conclusão vale para a hipótese de acordo celebrado judicialmente. $\mathrm{Na}$ conciliação judicial as possibilidades de transação tornam-se ainda mais amplas, podendo compreender restrição ao trabalho, mediante compensação, ainda quando não constitua a matéria objeto do processo ${ }^{83}$ e não exista nenhuma previsão no contrato de trabalho ou no acordo para a sua rescisão. O equilibrio do ajuste será avaliado pelo próprio juiz, que tem a indiscutivel prerrogativa de negar homologação de cláusula desnecessária ou exorbitante. ${ }^{84}$

82 Parte da doutrina nega a possibilidade de o impregado recusar promoção (MAGANO, Octavio Bueno. Do poder diretivo na empresa. São Paulo: Saraiva, 1982. n. 66, p. 128, MARANHÃO, Délio. Instituições de direito do trabalho. Sào Paulo: LTr, 2002. v. 1, p. 537, e BERNARDES, Hugo Gueiros. Alteração do contrato de trabalho. In: Curso de direito do trabalho - Obra em homenagem ao ministro e professor Mozart Victor Russomano. São Paulo: Saraiva, 1985. p. 323). A conclusão não sc harmoniza, todavia, com a regra do art. 468, da CLT, sendo mais acertado entender que o empregado está obrigado a prestar apenas os serviços para os quais foi contratado, podendo recusar légitimamente a atribuição de outros, ainda que por conta de promoção (assim RUSSOMANO, Mozarı Victor. Curso de direito do trabalho. Curitiba: Juruá. 2000. p. 138).

83 Cuida-se de decorrência do disposto no art. 584, inciso III, do CPC, verbis: "Art. 584 - Sào títullos executivos judiciais: ... III - a sentença homologatória de conciliação ou de transação, ainda que verse matéria não posta em juizo;"

84 A propósito. em termos gerais, com indicação de jurisprudência. MALLET, Estêvão. Procedimento sumarissimo trubalhista. São Paulo: LTr, 2002. n. 14, p. 47, especialmente nota 156. 
8. Interpretação

A interpretaçăo da cláusula de não-concorrência, a fim de definir a extensão das obrigações e dos direitos das partes, sujeita-se aos critérios hermenêuticos válidos para os contratos em geral ${ }^{85}$ e para o contrato de trabalho em particular.

No tocante à definição dos limites à liberdade de trabalho do empregado, tanto do ponto de vista objetivo, como espacial e temporal, adote-se exegese restritiva, conforme enunciado pela Corte de Cassação francesa, nos seguintes termos: "unc cluuse de non concurrance qui apporte une restriction au principe de la liberté du travail est d'interprétation stricte et ne peut êtrc' étendue au-delà de ses prévisions" 86 De idêntico modo, decidiu a Primeira Corte (ivil do Tribunal Federal suiço: "En matière de prohibition de faire concurrence, lés restrictions l'gales à l'autonomie des parties tendent à protégù le partenaire le plus faible contre des engagements de nature à entraver inéquitablement son avenir économique et à empêcher un changement d'emploi, sans même que souvent l'employé se rende compte exactement de la portée de son obligution...S'ugissant de conditions imposées par l'emploveur au moment de la conclusion du contrut, des doutes relatifs à l'étendue de l'interdiction doivent être intrprétés restrictivement, voire contre le rédacteur de la clause.." 87

Merece especifica referência, ainda, a possibilidade de aplicação da regra do art. 423, do Código Civil, salvo quando, provada a ocorrência de complexas negociações - como por vezes se dá com empregados admitidos para elevados cargos -, demonstrar-se não haver sido celebrado contrato de adesão.

Estabelecida cláusula de não-concorrência em contrato civil de prestação de serviço, havendo, por meio de decisão judicial, requalificação do vínculo, para sujeitá-lo à legislação trabalhista, a restrição em principio permanece. Decorrência do disposto no art. 170 , do Código Civil. ${ }^{88}$

85 I. e., arts. 112, 113, 114, do Código Civil, etc.

86 Corte de Cassação, Seção Social, 3 de feverciro de 1999. De mudo parcialmente divergente, fazendo referência a "une interprétation téléologique, plus qu'umc imterprétation restrictive". Raymonde Vatinet, Les principes mis en oeuvre par la iurisprudence relative aux clauses de non-concurrance 'n droit du travail cit., p. 539. Analogamente, afirmando que "We must construt' the noncompetition clause 'so as to make the extent and character of its operation reasonable "', United States Court of Appeals for the Ninth Circuil em Western Medical v. Johinson (n. 93-35862), decisão de 09.06.95.

87 Decisão de 22 de março de 1966. tomada no caso H. Séquin et ses fils contre Werdenberg.

88 Sobre os limites de aplicação da norma indicada. cf., em termos gerais, DEL NERO. João Alberto Schützer. Conversáo substancial do negócio juridico. Rio de Janeiro: Renovar. 200I passim. 
Como já assinalado, a restrição à concorrência tem de mostrar-se. alím de necessária, também equilibrada, sopesados os aspectos objetivo, espacial e temporal da limitação imposta ao empregado, e considerada a compensação que the é atribuída.

O equilíbrio da cláusula é avaliado no momento em que sc devam produzir os seus efeitos, ou seja, a partir do momento em que se inicia, em tese, a restrição à atividade do empregado. ${ }^{89} \mathrm{O}$ ajuste tem de ser regular não apenas no momento em que foi firmado. É preciso que se mantenha regular. Do contrário, fica a obrigação comprometida. É o que acontece, por exemplo, se a compensação atribuída ao trabalhador. embora adequada na altura, sofre desatualização pelo passar do tempo, em virtude da inflação. Do mesmo modo, a superveniente ausência de necessidade da cláusula torna insubsistente a obrigação, por falta de legítimo interesse do empregador, como estatuído, aliás, no art. 340 c, n. 4, do Código suiço das obrigações: "La prohibition de faire concurrence cesse s'il est établi que l'employeur n'a plus d'intérêt récl à ce qu'elle soit maintenue"

Sendo excessivos os limites da obrigação de não-concorrência, configura-se invalidade. Mas qual a extensão dessa invalidade? Em outros turmos, pode-se eliminar judicialmente o excesso, podando-se apenas a parte exorbitante da obrigação imposta ao empregado, mantida a obrigação de não-concorrência, ou, ao contrário, fíca toda a cláusula comprometida? Os tribunais ingleses e norte-americanos relutaram, durante muito tempo, em reformular os termos de obrigação contratual de não-concorrência, para torná-los regulares. receosos de que. se o fizessem. estimulariam os empregadores a adotar limites cada vez mais largos, diante da garantia de intervenção judicial corretiva. ${ }^{90}$ Prevaleceu afinal, porém, a idéia de que, observados certos limites, "a clause which is over-wide in its scopes may be saved" 91 De acordo com Harlan M. Blake, "if the court is persuaded that employer's policy and practice with respect to employee restraints generally is fair and designed only to protect legitimate interests, the court should tailor the covenant to provide such protection with a minimum burden to the employee" 92

Não há, na verdade, razão para privar-se de validade todo o ato se parte dele pode permanecer. Incide, no particular, o disposto no art. 184, do Código Civil, tanto mais diante da ampliação da possibilidade de revisão judicial dos contratos, como se deduz dos

89 VATINET, Raymonde. Les principes mis en oeuvre par la jurisprudence relalive anx clauses de non concurrance en droit du travai. cit., p. 536.

90 DEAKIN, Simon; MORRIS, Gillian S. Labor Law'. London: Butterworths, 2003. p. 345. No Direito norteamericano, sobre a aplicação da "general contract doctrine of severance" no campo das cláusulas de nãucompetição, cf. BLAKE, Harlan M. Employee agreements not to compete. cit., p. 681 .

9I DEAKIN, Simon; MORRIS, Gillian S. Labor Law: cit. p. 345.

92 BLAKE, Harlan M. Employee agreements not 10 compete, cit., p. 683. 
arts. 157 e 478, do mesmo Código (ivil. Se a correção do excesso não-violenta a vontade das partes, deve ser admitida, em ruspeito, inclusive, ao princípio da conservação dos atos jurídicos, ${ }^{9}$ permitida até a elıvação da compensação devida ao empregado. Essa, aliás, a solução propugnada pela doutrina francesa ${ }^{94} \mathrm{e}$, ainda, a adotada, de modo expresso, pclo Código suiço das obrigações, em cujo art. 340a, n. 2, prcceitua-sc: "Le juge peut réduire selon sa libre appréciation une prohibition excessive, en tenant compte de toutes les circonstances; il aura égard. d'une manière équitable, à une éventuelle contre-prestation de l'employeur." gs

10. Motivo determinante da extinção do contrato de trabalho e obrigação de nãoconcorrência

Em principio a eficácia da cláusula de não-concorrência não depende do motivo determinante da extinção do contrato de trabalho. Assim, quer se verifique dispensa com ou sem justa causa, demissão, aposentadoria ou simples distrato, por acordo, permanecem os direitos e as ohrigações decorrentes do ajuste.

No Direito suiço ressalva-se que a obrigação de não-concorrência cessa "si l'employ'ur résilie le contrat sans que le travailleur lui ait donné un motif justifié ou si le travailleur résilie le contrat pour un motif justifié imputable à l'employeur" 96 Não há razão para adotar-se a mesma solução no Direito brasileiro, o que não impede, todavia, que o próprio acordo sobre não-concorrência estabeleça regras específicas, privando de ¿ficácia a cláusula ım determinadas circunstâncias.

Em alguns casos, porém, o resultado é outro, ficando a eficácia da cláusula comprometida em virtude do motivo determinante da rescisão do contrato de trabalho, independentemente de previsão expressa. Havendo extinção do estabelecimento (CLT, arts. 497 e 502), por excmplo, é evidente que não permanece a obrigação de nãoconcorrência, porque a restrição deixa de ter interesse. Do mesmo modo, em caso de morte do empregado, perde a cláusula o seu objeto. A observação é importante porque

93 A propósito. em termos gerais. TRABUCCHI, Alherto. Istituzioni di diritlo civile. Padova: CEDAM, 1956. n. 81 , p. 173 e segs.

"GAUDU, François: VATINET, Raymond. Les contrats du travail. cit, n. 311. p. 263. Sobre a evolução em geral do poder do juiz para rever. no Direito francês, prestações contratualmente estabelecidas. para equilibrá-las, TERRÉ, François; SIMLER, Philippe: LEQUETTE, Yves. Droit civil - Les obligations. Paris: Dalloz. 1999, n. 297, p. 289.

${ }^{2}$ Cf.. em jurisprudência, a decisão tomada pelo Tribunal I edural suiço em 17.05.83 (109 II 120).

96 Código suiço das obrigaçōes, art. 34Gic, n. 2. No Direito norte-americano por vezes se leva em conta o motivo da extinção do contrato, para avaliar a possibilidade de atribuir-se maior ou menor eficácia à cláusula de nãocompetiçăo (cl. BLAKE. Harlan M. Employee agreements not to competi. cit., p. 685). 
tanto em um caso como no outro torna-se indevida a compensação financeira atribuida como contrapartida à restrição ao trabalho.

\section{Descumprimento da cláusula de não-concorrência}

A obrigação de não-concorrência tem de ser cumprida de boa-fé, nos exatos termos do art. 422, do Código Civil. Expedientes fraudulentos, destinados a burlar a restrição pactuada, não impedem a configuração de mora do empregado. A violação não deixa de ocorrer, por exemplo, somente por ser a atividade prestada não diretamente pelo próprio trabalhador, que accitou restringir sua atuação, mas por meio de empresa por ele constituida. Bem decidiu, a propósito, o Supremo Tribunal de Justiça de Portugal ao afirmar: "seria inaceifável que dois individuos obrigados uo dever de não-concorrência se libertassem disso constituindo uma pessoa colectiva" 97

Descumprida a obrigação imposta ao empregado, incide o disposto no art. 475, do Código Civil. Ao empregador é dado postular, sem prejuizo das perdas e danos, a restituição dos valores pagos em compensação à restrição pactuada ${ }^{98}$ ou a execução especifica da obrigação, além da pena eventualmente cominada (Código Civil, art. 4l1). Aplica-se, na última hipótese, a regra do art. 461, do CPC, admitindo-se a imposição de multa diária ou a adoção de outras medidas, para assegurar prestação de tutela específica. Não é preciso que tal possibilidade tenha sido admitida de forma expressa no acordo sobre não-concorrência, como na legislação suiça, ${ }^{99}$ porque no Direito brasileiro ela decorre naturalmente da lei.

O descumprimento da obrigação pode sur apenas parcial. Pense-se no empregado que, obrigado a não exercer certa atividade por dois anos, restringe sua atuação durante apenas um ano, ignorando a proibição, porém, no período final. Concebese, outrossim, a hipótese de, excluído o exercicio de duas diferentes atividades, haver o descumprimento da obrigação de não-concortência em relação a uma e não a outra.

97 Processo n. 97B268, Rel. Juiz Sả Couto, julgado em 12.06.97. Já assim, no Direito italiano, ASCARELLI, Tullio. Teoria della concorrenza e dei beni immateriali. Milano: Giuffrè, 1957. p. 51.

98 Em jurisprudéncia, em casos análogos: "Comprovada a inexecuçào total do contrato, caracterizada pela não entruga do imóvel prometido vender, cabível é a solução do negócio jurídico com o retorno das partes ao estado de origem" (TJ-RJ, 15² Câm. Cív., Ap. Civ. n. 2002.001.16197. Rel. Des. José Pimentel Marques, julg. em 13.08.03) e "Nada autoriza concluir que, vencida a divida, apenas possa o credor cobrá-la mas não obter a rescisão do contrato e com isso a volta do estado anterior à pactuação" (2 $2^{\circ}$ TACiv. SP, $12^{\text {a }}$ Câm., Ap. s/ Rev. N. 776.055-00/0, Rel. Juiz. Arantes Thcodoro julg. em 13.02.2003).

99 Dispõe o Código suiço das obrigaçōes, no art. 340b, n. 3: "L'employeur peut exiger, s'il s'en est expressément résenvé le droit par écrit. outre la peine conventionnelle et les dommages-intérêts supplimentaires éventuels, la cessation de la contravention. lorsque cette mesure est justifiee par l'importance des intérêts lésés ou menacés de l'employeur et par le comportemenı du travaillıur" A doutrina sobre o tema pode ser encontrada em W'YLER, Rémy. Droit du travail. cit., p. 455. 
Mantida a possibilidade de deferimento de indenização e de tutela específica, a pena cominada deve ser proporcionalmente reduzida, nos termos do art. 41.3, do Código Civil, ${ }^{100}$ como previsto, aliás, na lei belga. ${ }^{101}$ Em caso de pedido de resolução da obrigação (Código Civil, art. 475), a restituição da compensação atribuída ao empregado igualmente se sujeita a redução proporcional.

Se é o empregador que descumpre a cláusula de não-concorrência, não quitando a compensação ajustada, cabe ao empregado optar por pedir a resolução do ajuste, com sua liberação da obrigação assumida, ou o pagamento da compensação. ${ }^{102} \mathrm{O}$ prazo prescricional não se conta da rescisão do contrato, mas, sim, do vencimento da prestação. $^{103}$

\section{Impugnação da cláusula}

A validade e a adequação da cláusula de não-concorrência podem tanto ser discutidas em reclamação ajuizada pelo empregado, com pedido de anulação do ajuste ou pagamento das parcelas pactuadas, acrescidas de valores adicionais, por conta do caráter desproporcional da limitação estabelecida, ${ }^{104}$ como, igualmente, em reclamação proposta pelo empregador, para recebimento de indenização ou imposição de multa decorrente de seu descumprimento, constituindo, nesse último caso, questão prejudicial (C.PC, art. 469, inciso III).

A competência para exame da causa. por aplicação da regra geral do art. 65I, caput, da CLT, é do juizo do local em que prestados os serviços ao tempo do extinto contrato de trabalho, no qual se pactuou a obrigação de não-concorrência, não o do local em que se dá a violação da obrigação. Executado no estrangciro o contrato, incide o disposto no art. $651, \S 2^{\circ}$, da CLT.

${ }^{100} \mathrm{Na}$ jurisprudència anterior ao vigente Código Civil: "O art. 924 do Código Civil então vigente autoriza o magistrado a reduzir proporcionalmente a pena estipulada para o caso de inadimplemento".(TJ-RJ, $8^{\text {a }}$ Càm. Civ., Ap Civ. n. 2003.001.30212. Rel. Des. Marco Aurelio Froes, julg. cm 13.04.04).

${ }^{101}$ Preceitua a parte final do art. 65. da Lei de 3 de julho de 1978, ao tratar do descumprımento da obrigação de näo-concorrência pelo empregado: “...à la demande de l'ouvrier: le juge peut réduire le momant de l'indemnité fixée convintionnellemerit. en tenant comple notamment du dommage causé 't de la durée réelle de la période pendunt laquelle la claise a été respectée"

102 VATINET, Raymonde. Les principes mis en oeuvre par la jurisprudence relativi aux clauses de nonconcurrance en droit du travail. cit.. p. 536.

103 Sobre o prazo prescricional um caso de lesão pós-contratual, cf. SILVA, Homero Batista Mateus da. Estudo crítico da prescrição trabalhista. São Paulo: LTr, 2004. p. 191.

104 Antes. item 9. 
13. Omissão da existência da cláusula pelo empregado e responsabilidade do novo empregador

A cláusula de não-concorrência, quando prevista em contrato de trabalho, vincula apenas empregado c empregador. Para outras empresas ou empregadores constitui res inter alios, o que não exclui a possibilidade de surgimento de responsabilidade de terceiros, responsabilidade que será, todavia, de natureza aquiliana e não contratual. ${ }^{105} \mathrm{~A}$ diferença é importante porque torna necessária, não havendo previsão de responsabilidade objctiva, a demonstração de culpa do terceiro, não exigivel no caso de inadimplemento contratual, em que ao contratante inadimplente é que se atribui o ônus de provar a ausência de culpa, em virtude da ocorrência de caso fortuito ou força maior. ${ }^{100}$

Para que haja culpa, de rigor tenha o terceiro ciência do impedimento ao trabalho que pesa sobre o empregado admitido. Ao antigo empregador, que pretende responsabilizar o novo, cabe o ônus de provar o conhecimento da restrição, fato constitutivo da responsabilidade do último (CLT, art. 818, e CPC, art. 333, inciso I). A notificação do novo empregador, pelo antigo, basta para que se afaste a alegação de ignorância e permite responsabilizar o primeiro, solidariamente com o empregado (Código Civil, art. 942, parte final), pelos danos causados com a concorrência.

O empregado, ao omitir do novo empregador a existência da cláusula de não-concorrência, incorre no que a doutrina francesa chama de dol par réticence. ${ }^{107}$ Tomando o novo empregador ciência da limitação, seja por conta de comunicação proveniente do antigo empregador, seja por outro meio, poderá rescindir com justa causa o contrato de trabalho. O mesmo ocorre caso tenha sido falsamente informada a inexistência de restrição. Se, diversamente, o empregado revelou o impedimento e mesmo assim deu-se a sua admissão, tal fato dcixou de bastar à dispensa motivada. Foi aceito pelo novo empregador, o que elide sua invocação como motivo relevante para a rescisão do contrato.

São Paulo, novembro de 2005.

${ }^{105}$ GAUDU, François; VATINET, Raymond. Les contrats du travail. cit., n. 315, p. 266.

${ }^{106}$ Cf. arts. 186 e 927, do Código Civil, em confronto com arts. 389 e 393. do mesmo Código, aplicáveis à responsabilidade contratual. Em doutrina, GONÇALVES, Carlos Roberto. Comentários ao Código Civil. São Paulo: Saraiva, 2003. v. 11, p. 26. Mais amplamente, DE CUPIS, Adriano. /l dano - Teoria generale della responsabilitá civile. Milano: Giuffrè, 1946. p. 94 e segs., e CHIRONI, G. P. La colpa nel dirillo civile odierno - Colpa extra-contratuale. Torino: Fratelli Bocca, 1906. v. II, n. 552, p. 592 e segs.

${ }^{107}$ GAUTIER, Pierre-Yves. Les interactions du droil civil el du droit du travail. In: LES SOl'RCES du droit du travail. Paris: Presses Universitaires de France, 1998. p. 135. 
Referências

ALONSO OLEA, Manuel. Derecho del trahajo. Madrid: Universidade de Madrid. 1974.

ALONSO OLEA, Manuel. Introdução ao direito do trabalho. Curitiba: Gênesis, 1997.

ARAUJO. Francisco Rossal de. A boa-fé no contrato de emprego. São Paulo: LTr, 1996.

ARON, Raymond. Dezoito lições sobre a sociedade industrial. São Paulo: Martins Fontes, 1981.

ASCARELLI. Tullio. Teoria della concorrenza e dei beni immateriali. Milano: Giuffrè, 1957.

BARAC.AT, Eduardo Milléo. A boa-fé no direito individual do trabalho. São Paulo: LTr, 2003.

BELTRAN, Ari Possidonio. A cláusula de não-concorrência no direito do trabalho. Revista do Advogado. São Paulo. n. 54, p. 67, dez. 1998.

BERNARDES, Hugo Gueiros. Alteração do contrato de trabalho. In: ClIRSO de direito do trabalho

Obra em homenagem ao ministro ' professor Mozart Victor Russomano. São Paulo: Saraiva. 1985.

BLAKE, Harlan M. Employee agreements not to compete. Harvard Law Review, v. 73. n. 4, p. 625 e segs, February 1960.

CALAMARI, John D.; PERILlO, Joseph M. The law of contracts. Minnesota: West Publishing. 1970.

CALLAHAN, Maureen B. Pos-employment restraint agreements: A reassessment. L'niversity of Chicago Law Review, Chicago, n. 52, p. 707 e segs. Summer. 1985.

CESARINO JÚNIOR, A. F.; CARDONE, Marly. Direito social. São Paulo: LTr, 1993. v. 1.

CORRADO, Renato. Il lavoratore nell'organizzazione dell'impresa. In: NUOVO trattato di diritto del lavorn. Padova: CEDAM, 1971. v. II.

CORRADO, Renato. Trattato di diritto del lavoro. Torino: UTET, 1969. v. III, n. 118.

DE MASI, Domenico. Il futuro del lavoro. Rizzoli: Milano, 1999.

DEAKIN, Simon: MORRIS, Gillian S. Labor Law: London: Butterworths, 2003.

DEL NERO, João Alberto Schützer. Conversão substancial do negricio juridico. Rio de Janeiro: Renovar, 2001.

DELGADO, Mauricio Godinho. ('urso de direito do trabalho. São Paulo: LTr. 2002.

DORIA, A. de Sampaio. Principios constitucionais. São Paulo: São Paulo Editora, 1926. 
FEKETE, Elisabeth Kasznar. O regime juridico do segredo de industria e comércio no direito brasileiro. Rio de Janeiro: Forense, 2003.

FERNANDES, António Lemos Monteiro. Direitu do trabalho. Almedina: Coimbra, 1999.

FERRARA. Francesco. Truttato di diritto civile italiano. Roma: Athenaeum, I92I.

GALBRAITH, John Kenneth. Le nouvel état industriel. Paris: Gallimard, 1979.

GAUDU, François; VATINET, Raymond. Les contrats du travail. Paris: LGDJ, 2001. n. 317.

GAUTIER, Pierre-Yves. Les interactions du droit civil et du droit du travail. In: LES SOURCES du droit du travail. Paris: Presses Universitaires de France, 1998.

GAVALDA, Natacha, Les critères de validité des clauses de non-concurrance en droit du travail. Droit Social, n. 6, p. 586, juin 1999.

GOFF, Jacques lc. Droit du travail et socièté, Les relations individuelles de travail. Paris: Presses Universitaires de Rennes, 2001.

HABERMAS, Jürgen. Técnica e ciência como ideologia. Lisboa: Edições 70, 1986.

MAGANO, Octavio Bueno. Do poder diretivo nu empresa. São Paulo: Saraiva, 1982.

MALLFT, Estêvão. Procedimento sumarissimo trabalhista. São Paulo: LTr, 2002.

MARANHÃO, Délio. Instituições de direito do trabalho. São Paulo: I.Tr, 2002. v. 1.

MARTINS, Sergio Pinto. Direiro do Trabalho. São Paulo: Atlas, 2003.

MÉMENTO pratique Francis Lefebvre. Levallois: Éditions Francis Lefebvre, 1995. n. 2.789.

MENDONÇA, J. X. Carvalho de. Tratado de Direito Commercial Brasileiro. Rio de Janeiro: Freitas Bastos, 1933. v. II, Livro I.

MIRANDA. Jorge. Munual de direito constitucional. Coimbra: Coimbra Editora, 1998. Tomo IV.

MIRANDA, rrancisco Cavalcanti Pontes de. Comentários à Constiluiçâo de 1967. Rio de Janeiro: Forense, 1987. Tomo V.

OLIVEIRA, Oris. de A exclusão de concorrência no contrato de trabalho. São Paulo: s. e. p. (tese), s. d. p., p. 256 ,

PEREIRA, ('aio Mário da Silva. Les̃̃o nos contratos bilaterais. Rio de Janeiro: l'orense, 1949.

QLINTAS. Paula: QUINAS, Helder. Código do Trahalho anotado e comentado. Coimbra: Almedina. 2004. 
RUSSOMANO, Mozart Victur. Curso de direito do rrabalho. Curitiba: Juruá. 2000.

SALOMÃO FILHO, Calixto. Condutas tendentes à dominação dos mercados - análise juridica, São Paulo. s. e. p. (tese), 2001, p. 149.

SILVA, Homero Batista Mateus da. Estudo crítico da prescrição trabalhisıa. São Paulo: LTr, 2004. TFRRÉ, François; SIMLER, Philippe; LEQUETTE, Yves. Droit civil Les obligations. Paris: Dalloz, 1999.

TRABUCCHI, Albertu. Istituzioni di diritto civile. Padova: CEDAM. 1956.

LE TRAVAIL dans le monde. (ienèv: Bureau International du Travail, 1997.

VATINET, Raymonde. Les principes mis en oeuvre par la jurisprudence relative aux clauses de nun-concurrance en droit du travail. Droit Social, p. 536, juin 1998.

WYLER, Rémy. Droit du travail. Berne: Staempfli, 2002.

XAVIER, Bernardo da Gama Lobo. Curso de Direito do Trabalho. Lisboa: Verbo, 1999. 